\title{
Arrogance on human cloning may pose a threat to biotechnology
}

\section{Russ Hoyle}

For some time, Carl Feldbaum, president of the Biotechnology Industry Organization (BIO; Washington, DC), has believed that the greatest threat to emerging biotechnology companies will arise not such depredations as an abrupt drying up of research funds, or even controversial new scientific methods, but from the industry mishandling troubling ethical problems. At issue is the delicate and mysterious course of public and scientific acceptance of new technologies and their profound impact on the moral underpinnings of society.

There is currently no issue with greater potential to undo public confidence in the biotechnology industry than human cloning. Growing anecdotal evidence suggests that certain segments of the scientific community, particularly in the growing area of reproductive fertility, have been disturbingly quick to accept the inevitability of human cloning and are already publicly trumpeting their right to proceed without constraints.

"I see a total shift in the burden of proof to saying that unless you can prove there is actually going to be harm, then we should allow it," New York Times' correspondent Gina Kolata recently quoted an expert on reproductive law at the Chicago-Kent College of Law, Lori Andrews, as saying. People now feel that "'the risks aren't that great," she added.

Despite the human propensity to accommodate and even accept the most initially horrifying scientific advances, some in the biotechnology community dispute just how widespread this sea change about the propriety of human cloning research has become. Indeed, public opinion polls taken in the US since last March, in the wake of news that a sheep named Dolly was cloned by researchers at the Roslin Institute near Edinburgh, show strong opposition to human cloning.

Nonetheless, the initially cautious reaction of the scientific community may already be moving quickly beyond public disapproval and concern. At a December conference in Chicago on the ethics and reproductive technology, for example, biologist Richard Seed of the Illinois Institute of Technology announced that he was assembling a research team to clone a human being, which he reportedly declared may be easier than some scientists think. Not surprisingly, Seed is reportedly interested in developing cloning as a commercial venture for infertile couples. He is only one of a number of such researchers around the country.

This apparent new surge of scientific aggressiveness about human cloning, unfortunately, is precisely what legislation proposed by President Clinton's National Bioethics Advisory Commission last June was intended to dampen. As one commission member quipped, "It now looks prescient, doesn't it?" The legislation calls for a five-year moratorium on research on cloning techniques "to create a child," but would not prohibit "the use of these techniques to clone DNA in cells" or "the cloning of animals." Under the leadership of Princeton President Howard Shapiro, the commission called for a time out on human cloning research to give Americans time to debate its daunting social, religious, ethical, and legal implications.

The new scientific arrogance, if that is what it is, may create new political hazards for the biotechnology industry. BIO's Feldbaum, who has criticized the NBAC's proposed legislation on the grounds that it does not sufficiently safeguard legitimate areas of scientific inquiry, such as human fetal tissue research, is now under greater pressure to find support for the concept of the human cloning moratorium while not giving way on other cloning research.

"Before we rush ahead," says Feldbaum, "We need to ask ourselves these questions about the social and ethical implications of human cloning." The danger of doing otherwise, he says, could "create a gap that could become a chasm between the scientific community and politicians, the public and religiously-fueled groups that could make life more difficult and uncomfortable." Indeed, scientific hardliners on human cloning who are impatient with the ethical and religious niceties of their research may turn out to be their own worst enemies. The concern is that they could bring about what Feldbaum and others fear most: a public backlash that might result in an outright ban on cloning research.

That is certainly one way to start a national debate on human cloning. A more productive course, however, may be to mount a campaign, perhaps undertaken by an organization such as BIO or the president's bioethics commission, with the broad goal of sensitizing scientific researchers to public, political and religious concerns about human cloning. Part of the problem, according to Steven Holtzman, who is the chief business officer for Millenium Pharmaceuticals (Cambridge,
MA), as well as a member of the President's commission and the head of BIO's bioethics committee, may be a misunderstanding of what the NBAC report actually proposed.

Holtzman believes that confusion grew out of the commission's public emphasis on justifying a research moratorium based solely on health and safety factors-after all, cloning Dolly meant sacrificing literally hundreds of lambs before it was successful. Such a cost attached to human cloning research is clearly unacceptable. Still, Holtzman points out, some 60 pages of the 110 -odd page report catalogued the social, ethical, religious and legal questions raised by human cloning. Those considerations, he says, are the real foundation for the moratorium.

Holtzman says the misunderstanding has led to a false distinction that appears to constrain one sort of research while approving of another. "This argument is not about science," he says. Holtzman, like many others, has few doubts that researchers will find safe ways to clone humans. But then what? The problem, he insists, is a matter of ethics and morality. Indeed, the commission report noted precisely that "concerns relating to the potential psychological harm to children and effect on the moral, religious and cultural values of society merited further reflection and deliberation."

Even so, while the commission may have outlined the ethical and social problems, it offered no conclusions or guidance on the troubling and complex issues involved. Is cloning humans a legitimate reproductive practice, like, say, artificial insemination? Would cloned humans, perhaps created by unscrupulous researchers as "factories" for replacement parts, have the right to choose their own destiny? Would cloned children have the same rights as natural children?

These are daunting and historic questions. They arise, unlike those raised by other reproductive technologies, from the proposition that it is now technically possible to create a child genetically identical in all respects to a pre-existing individual. That has never happened before. The biotechnology industry, together with responsible leaders of the scientific community, should move decisively to support a temporary ban on human cloning research. You don't have to believe you're opening a Pandora's box to put off actually prying off the lid until you've looked at the goods more closely. 